\title{
A Proteomic Screen for Presynaptic Terminal N-type Calcium Channel (CaV2.2) Binding Partners
}

\author{
Rajesh Khanna ${ }^{1, *}$, Alexandre Zougman ${ }^{2}$ and Elise F. Stanley ${ }^{1, *}$ \\ ${ }^{1}$ Cellular and Molecular Biology Division, Toronto Western Research Institute, University Health Network, Toronto, Ontario, Canada \\ ${ }^{2}$ Protana Analytical Services, Toronto, Ontario, Canada
}

Received 6 September 2006, Accepted 7 December 2006

\begin{abstract}
N type calcium channels (CaV2.2) play a key role in the gating of transmitter release at presynaptic nerve terminals. These channels are generally regarded as parts of a multimolecular complex that can modulate their open probability and ensure their location near the vesicle docking and fusion sites. However, the proteins that comprise this component remain poorly characterized. We have carried out the first open screen of presynaptic CaV2.2 complex members by an antibody-mediated capture of the channel from purified rat brain synaptosome lysate followed by mass spectroscopy. 589 unique peptides resulted in a high confidence match of 104 total proteins and 40 synaptosome proteome proteins. This screen identified several known CaV2.2 interacting proteins including syntaxin 1, VAMP, protein phosphatase $2 A, G_{0 \alpha}, G \beta$ and spectrin and also a number of novel proteins, including clathrin, adaptin, dynamin, dynein, NSF and actin. The unexpected proteins were classified within a number of functional classes that include exocytosis, endocytosis, cytoplasmic matrix, modulators, chaperones, and cell-signaling molecules and this list was contrasted to previous reports that catalogue the synaptosome proteome. The failure to detect any postsynaptic density proteins suggests that the channel itself does not exhibit stable trans-synaptic attachments. Our results suggest that the channel is anchored to a
\end{abstract}

\footnotetext{
Abbreviations: $\mathrm{CaV} 2.2, \mathrm{~N}$ type $\mathrm{Ca}^{2+}$ channel; PBS, phosphate buffered saline; CAZ, cytoskeletal matrix of the active zone; CASK, calcium/calmodulin-dependent serine protein kinase; ERC/CAST, ELKS-Rab6-interacting protein-CAST/CAZ-associated structural protein; ER, endoplasmic reticulum; IP, immunoprecipitation; LC/ MS/MS, liquid chromatography coupled with tandem mass spectroscopy; NSF, n-ethylmaleimide sensitive fusion protein; RIM, Rab3 interacting protein; PSD postsynaptic density; SV synaptic vesicle.
}

*To whom correspondence should be addressed.

Tel: 416-603-5131; Fax: 416-603-5745

E-mail: estanley@uhnres.utoronto.ca cytoplasmic matrix related to the previously described particle web.

Keywords: Active zone, Cytoplasmic matrix, Particle web, Transmitter release site, Synaptosome, Scaffold

\section{Introduction}

The rapid release of neurotransmitters from nerve terminals at synapses occurs at specialized areas on the presynaptic transmitter release face opposing postsynaptic receptor regions that are described morphologically as active zones or functionally as transmitter release sites. Presynaptic $\mathrm{Ca}^{2+}$ channels play a crucial role by admitting the $\mathrm{Ca}^{2+}$ ions that bind to and gate secretory vesicle fusion and discharge. Functional, biochemical, morphological and ultrastructural evidence suggest that the $\mathrm{Ca}^{2+}$ channel is an integral element of the transmitter release apparatus (reviewed in: Stanley, 1997). The channel has been suggested to be physically linked to the release apparatus via a number of protein anchoring mechanisms including the SNARE proteins (Ishikawa et al., 1993; El Far et al., 1995; Sheng et al., 1998; Atlas, 2001), modular adaptor proteins CASK and MINT (Maximov et al., 1999; Spafford et al., 2002), and via the matrix protein spectrin (Sunderland et al., 2000), amongst others. However, there is as yet no consensus on which, if any of these proteins serve as the primary channel anchor, nor as to the molecular constituents or organization of the entire $\mathrm{Ca}^{2+}$ channelassociated transmitter release site complex.

We have used an open screen, mass spectroscopy-based method to identify putative CaV2.2 complex partners in purified isolated rat brain synaptosomes. CaV2.2 was precipitated with a high-affinity antibody, Ab571, characterized previously (Li et al., 2004b; Khanna et al., 2006) and the complex partners were subjected to tandem mass spectroscopy (LC/MS/MS). The screen identified 40 synaptosome-specific 
proteins from a variety of functional classes that included both previously reported $\mathrm{Ca}^{2+}$ channel-binding proteins, as well as a number of novel members.

\section{Materials and Methods}

Rat brain lysate. Brains from 1 or 2 neonatal (1-2 days old) Sprague Dawley rats (Charles River, Quebec) were extracted in icecold phosphate buffered saline (PBS; Gibco BRL/Invitrogen Inc.) and homogenized with 10 strokes using a hand-held glass homogenizer (Thomas Scientific) in modified RIPA lysis buffer: $50 \mathrm{mM}$ Tris- $\mathrm{HCl}, \mathrm{pH} 8,1 \% \mathrm{NP}-40$ (Igepal), $150 \mathrm{mM} \mathrm{NaCl}, 0.5 \%$ $\mathrm{Na}$ deoxycholate, and $1 \mathrm{mM}$ EDTA, and supplemented with protease inhibitors: $1 \mu \mathrm{g} / \mathrm{ml}$ leupeptin, $2 \mu \mathrm{g} / \mathrm{ml}$ aprotinin, $1 \mathrm{mM}$ PMSF (Sigma) together with a protease inhibitor cocktail (Roche, Applied Science). In preliminary experiments we maximized the yield of solubilized CaV2.2 using a range of lysis buffers with a spectrum of ionic, non-ionic, and zwitterionic detergents. These were composed of RIPA buffer where the detergents were substituted with $2.5 \%$ digitonin, $2 \%$ sodium $n$-dodecyl sulfate (SDS), $1 \%$ Nonidet P-40 (NP-40), 2\% Triton X-114, 2\% Triton X$100,1 \% n$-dodecyl- $\beta$-D-maltoside, $1 \%$ saponin from Quillaja bark, or 2\% 3-[(3-Cholamidopropyl) dimethylammonio]-1-propanesulfonate (CHAPS). Following a brief low speed spin $(1,000 \times g$ for $10 \mathrm{~min})$ to eliminate nuclei and debris, the low speed supernatant was centrifuged at $100,000 \times \mathrm{g}$ for $1 \mathrm{hr}$ at $4^{\circ} \mathrm{C}$ to further remove insoluble material. The high speed supernatant was filtered through a $0.22 \mu \mathrm{m}$ syringe filter (Millipore) prior to use. We routinely observed $\geq 85 \%$ solubility of CaV2.2 (as assessed by Western blot analyses; see below) in lysates prepared with standard RIPA. Immuno-precipitation and immunoblot analysis were performed using standard procedures as described below. Protein concentrations were determined with BioRad protein assay reagent (Hercules).

Synaptosome preparation. Synaptosomes were prepared by a protocol adapted from a combination of reports published by us and others (Blackstone et al., 1992; Lau et al., 1996; Khanna et al., 2006; Khanna et al., 2006). Neonatal rat brains were used in this study to facilitate the solubilization of N-type channel complexes (Jones et al., 1997). Brains from Sprague Dawley (Charles River) rats were dissected into 10 volumes ice-cold homogenization buffer (0.32 M sucrose, 10 mM HEPES pH 7.4, 2 mM EDTA, supplemented with protease inhibitors) and homogenized using 10-15 strokes of a glass Teflon hand-held homogenizer. The homogenate was then spun at $1,000 \times g 4^{\circ} \mathrm{C}$ for 15 minutes to remove a nuclear fraction and cellular debris pellet. The supernatant from the low-speed spin (S1) was spun at $200,000 \times g 4^{\circ} \mathrm{C}$ for 45 minutes. The pellet from this spin (P1) was re-suspended in homogenization buffer and spun again at $200,000 \times g$ for an additional 45 minutes. This second pellet (P2) was re-suspended in HEPES buffer ( $50 \mathrm{mM}$ HEPES $\mathrm{pH}$ 7.4, $2 \mathrm{mM}$ EDTA plus protease inhibitors) and layered onto $4 \mathrm{ml}$ of 1.2 $\mathrm{M}$ sucrose and centrifuged at $230,000 \times g\left(4^{\circ} \mathrm{C}\right)$ for 30 minutes in a swinging bucket rotor. The gradient interphase was collected, diluted in 7-8 mls of ice-cold HEPES-buffered sucrose $(0.32 \mathrm{M}$ sucrose, $4 \mathrm{mM}$ HEPES, $\mathrm{pH}$ 7.4) and layered onto $4 \mathrm{ml}$ of $0.8 \mathrm{M}$ sucrose and re-centrifuged at $230,000 \times g$ for 15 minutes $\left(4^{\circ} \mathrm{C}\right)$ to yield pure synaptosomes. We observed a significant enrichment of presynaptic proteins in the pure synaptosome preparation as compared to crude synaptosomes (Fig. 1A). The pellet from this spin, which contains synaptosomal proteins, was re-homogenized in modified RIPA buffer; filtered through a $0.22 \mu \mathrm{m}$ syringe filter before its protein concentration was determined and fractions were stored at $-80^{\circ} \mathrm{C}$ until use.

Immunoprecipitation and western blotting. Fresh rat brain or synaptosome lysate, prepared as above, was pre-cleared by a $1 \mathrm{hr}$ incubation with $20 \mu \mathrm{l}$ of a $50 \%$ slurry of protein A beads (Pierce, Rockford, IL). The cleared lysate was then incubated overnight with various primary antibodies, using rabbit IgG as controls. The antibody-captured complexes were recovered with fresh protein A agarose beads ( $20 \mu \mathrm{l}$ original bead slurry per sample) by incubation with lysate-antibody mixture at $4^{\circ} \mathrm{C}$ for $2 \mathrm{hr}$. The beads were then washed three times with lysis buffer. Prior to electrophoresis on SDS polyacrylamide gels, protein samples were boiled in Laemmli sample buffer for $5 \mathrm{~min}$. Proteins were fractionated on $7.5 \%, 10 \%$ or $4-15 \%$ separating gels with $4 \%$ stacking gels. Apparent molecular weights were determined using broad range standards (BioRad) or high molecular weights standards (Invitrogen), as appropriate. Following electrophoresis, proteins were transferred to PVDF membranes (Invitrogen) for immunoblotting or stained with colloidal Coomassie blue (BioRad). Western blots were performed using standard procedures (Li et al., 2004b; Khanna et al., 2006). The membranes were blocked for $1 \mathrm{hr}$ in $5 \%$ skim milk powder in TBST ( $25 \mathrm{mM}$ Tris-Cl, pH 8.0, $125 \mathrm{mM} \mathrm{NaCl}, 0.1 \%$ Polyoxyethylene Sorbitan Monolaurate (Tween-20)) at room temperature. All antibody incubations were for $1 \mathrm{hr}$ at room temperature. Following incubations with primary antibody and secondary antibody (goat anti-rabbit IgG HRP, Stressgen; 1:5000), blots were washed extensively in TBST and probed with Enhanced Chemiluminescence reagent (NEN Life Science) before exposure to photographic film.

Antibodies. Antibodies used in this study are listed in Table 1.

Antibody conjugation to agarose-based matrix. To eliminate contamination of samples for proteomics analyses with antibodies, the CaV2.2 channel antibody (Ab571) was conjugated to an agarosebased matrix (Pierce). The conjugation was performed as per the manufacturer's instructions. Briefly, $200 \mu \mathrm{l}$ of AminoLink Plus Coupling Gel (Pierce) was added to a Handee Spin Cup Column (Pierce) and centrifuged at 3,000 $\times g$ for 30 seconds. Excess buffer was discarded and the gel was equilibrated with $0.4 \mathrm{ml}$ of coupling buffer ( $0.1 \mathrm{M}$ sodium phosphate, $0.15 \mathrm{M} \mathrm{NaCl}, \mathrm{pH} 7.2$ ), inverted 46 times to fully re-suspend the gel and then centrifuged. Excess buffer was discarded and the equilibration steps were repeated 2 more times. Then, $300 \mu \mathrm{l}$ of affinity-purified Ab571 antibody $(\sim 1.65 \mathrm{mg} / \mathrm{ml})$ was added to the spin cup and $3 \mu \mathrm{l}$ of $5 \mathrm{M}$ sodium cyanoborohydride was added to the gel. The spin cup was incubated overnight at $4^{\circ} \mathrm{C}$ on a rotator. The following morning, the tube housing the spin cup was placed into a new eppendorf tube and centrifuged. $0.4 \mathrm{ml}$ of coupling buffer was added to the spin cup and the tube was gently inverted 10 times and centrifuged. $0.4 \mathrm{ml}$ of quenching buffer ( $1 \mathrm{M}$ Tris- $\mathrm{HCl}, \mathrm{pH} 7.4$ ) was then added to the tube which was again inverted 10 times and centrifuged, with the flow-through buffer being discarded. Next, $0.4 \mathrm{ml}$ of quenching buffer was added to the gel along with $4 \mu \mathrm{l}$ of $5 \mathrm{M}$ sodium 
Table 1 (Methods). Antibodies used in this study

\begin{tabular}{llc}
\hline \multicolumn{1}{c}{ Antibody } & \multicolumn{1}{c}{ Source } & Dilutions $^{\mathrm{a}}$ \\
\hline $14-3-3(\mathrm{~m})$ & Covance Research Products (Berkeley, CA) & $1: 1000$ \\
$\beta$-actin (m) & Abcam Inc. (Cambridge, MA) & $1: 1500$ \\
AP180 (m) & BD Biosciences (Rockville, MD) & $1: 250$ \\
Bassoon (m) & Stressgen Bioreagents Corp. (Ann Arbor, MI) & $1: 200$ \\
CAST/ERC 1b/2 (p) & Synaptic Systems Labs. (Göttingen, FDR) & $1: 250$ \\
CaV2.2, Ab571 (p) & Stanley (Li et al., 2004b) & $1: 500$ \\
Dynamin (m) & Abcam Inc. & $1: 50$ \\
Munc-13-1 (m) & Synaptic Systems Labs. & $1: 300$ \\
Munc-18 (m) & BD Biosciences (Rockville, MD) & $1: 1000$ \\
Na ${ }^{+} \mathrm{K}^{+}$ATPase (m) & Developmental Studies Hybridoma Bank (DSHB; Iowa City, IA) & $1: 1000$ \\
NSF (m) & Synaptic Systems Labs. & $1: 1500$ \\
Piccolo (p) & Synaptic Systems Labs. & $1: 200$ \\
PSD-95 (m) & Affinity Bioreagents Inc. (Hornby, ON) & $1: 1000$ \\
Rab3 (m) & BD Biosciences & $1: 3000$ \\
RIM2 (p) & Synaptic Systems Labs. & $1: 200$ \\
SNAP-25 (m) & Calbiochem (La Jolla, CA) & $1: 1000$ \\
Syntaxin 1 (m) & Sigma (St. Louis, Missouri) & $1: 2000$ \\
\hline
\end{tabular}

${ }^{a}$ Dilutions used in Western blot analyses are listed. Abbreviations used: $\mathrm{m}$, monoclonal; $\mathrm{p}$, polyclonal. See text for other abbreviations.

cyanoborohydride and the tube was inverted 5 times. The tube was incubated at room temperature for 30 minutes on a rotator and centrifuged. The gel was equilibrated six times with $0.4 \mathrm{ml}$ equilibration buffer and then incubated with binding buffer $(0.14 \mathrm{M}$ $\mathrm{NaCl}, 0.008 \mathrm{M}$ sodium phosphate, $0.002 \mathrm{M}$ potassium phosphate and $0.01 \mathrm{M} \mathrm{KCl}, \mathrm{pH} 7.4$ ). Antibody coupled gel was stored in 0.4 $\mathrm{ml}$ binding buffer at $4^{\circ} \mathrm{C}$.

Immunoprecipitation using gel-conjugated Ab571. Fresh synaptosomes, prepared as described above, were immunoprecipitated with Ab571-coupled gel or rabbit IgG-coupled gel (control) at $4^{\circ} \mathrm{C}$ overnight. The beads were washed extensively (10 washes of $10000 \mathrm{X}$ matrix volume for a total of $30 \mathrm{~min}$ to $2 \mathrm{hr}$ ) to get rid of non-specific proteins. In order to get maximal recovery of target complexes from the beads, several methods of eluting proteins from the matrix were tried. These included boiling the beads in (i) RIPA buffer, (ii) in lysis buffer containing $1 \%$ Triton X100, (iii) in Laemmle sample loading buffer $(50 \mathrm{mM}$ Tris-HCl, $\mathrm{pH}$ $6.8 ; 2 \%$ SDS, $10 \%$ glycerol, $5 \% \beta$-mercaptoethanol, $12.5 \mathrm{mM}$ EDTA, $0.02 \%$ bromophenol blue) or (iv) incubating sequentially with $0.2 \%$ trifluoroacetic acid (pH 1.9) for $1 \mathrm{~min}$ followed by $1 \mathrm{M}$ ammonium bicarbonate ( $\mathrm{pH}$ 8.2) ( $\mathrm{pH}$ drop method; Schmitt-Ulms et al., 2004). The target complexes were extracted most efficiently from the matrix by boiling in Laemmle sample loading buffer for $15 \mathrm{~min}$, separated on a one-dimensional SDS-PAGE, and finally stained with colloidal Coomassie blue (Pierce). Selected bands, not present in control samples, were excised from the gel and subsequently in-gel digested with trypsin following routine protocols (Shevchenko, Wilm, Vorm and Mann, 1996). All protocols were conducted under sterile conditions. In addition, all samples were processed in non-pyrogenic, pre-lubricated microcentrifuge tubes (PGS Scientific, Frederick, Maryland) washed with 70\% ethanol and then HPLC-pure distilled water prior to use.
Mass spectrometric analysis. Peptide extracts were dried down and reconstituted with $0.1 \%$ formic acid. For the LC-MS/MS analysis, the samples were injected onto a $3 \mathrm{~cm} \mathrm{C18} \mathrm{trap} \mathrm{column}$ (inner diameter $200 \mathrm{~mm}$, packed with $5 \mathrm{~mm}$ media) using an autosampler (Agilent 1100 micro well-plate autosampler, Palo Alto, CA, USA). The peptides were eluted from the trap column onto a resolving analytical $10 \mathrm{~cm} \mathrm{C} 18$ column (inner diameter $75 \mathrm{~mm}$, packed with $3 \mathrm{~mm}$ media). A gradient pump (Agilent 1100 CapLC, Palo Alto, CA, USA) was running a gradient from $5 \%$ solvent $\mathrm{B} /$ $95 \%$ solvent $\mathrm{A}$ to $60 \%$ solvent $\mathrm{B} / 40 \%$ solvent $\mathrm{A}$ in $15 \mathrm{~min}$ (solvent A: $0.1 \%$ formic acid, $5 \%$ acetonitrile; solvent B: $90 \%$ acetonitrile, $0.1 \%$ formic acid). The LC setup was connected to an ion trap mass spectrometer (LCQ DeCa XP, Thermo, San Jose, CA, USA) using a nanoelectrospray source (Proxeon, Odense, Denmark).

Computational protein identification. Proteins were identified by searching MS/MS data utilizing the MASCOT search engine (Matrix Science; http://www.matrixscience.com) based on the entire NCBI database (Perkins, Pappin, Creasy and Cottrell, 1999). All identified proteins corresponded to the molecular weight based on the sample position in the gel.

\section{Results}

Rat brain synaptosomes. We used Western blots to test for synapse-related proteins in lysates of purified synaptosomes and whole brain solubilized in denaturing detergents (Laemmli buffer). CaV2.2, the subject of the present study, was identified with Ab571. This protein was present in both the brain and synaptosome lysates and was significantly enriched in the latter. Similarly, the SNARE-complex-related 

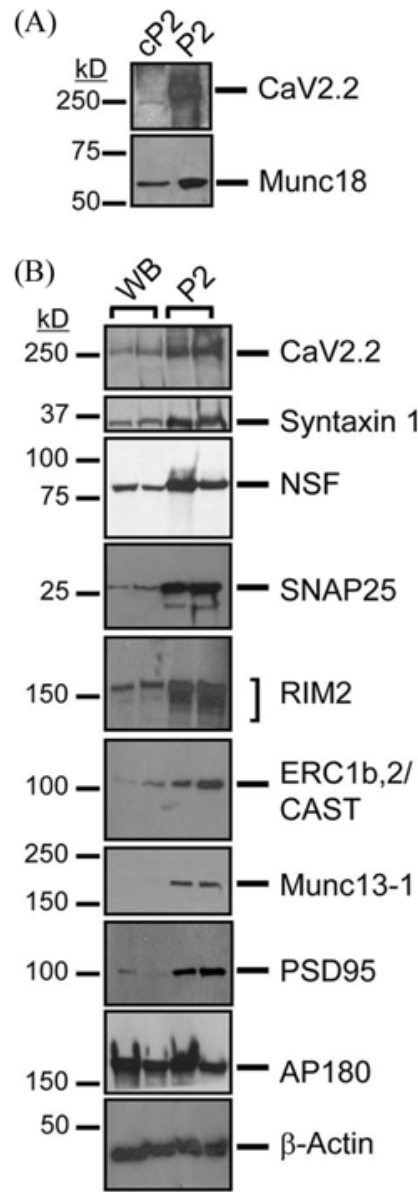

Fig. 1. Synaptic protein enrichment in purified synaptosomes. (A) Comparison of protein recovery in crude P2 (cP2) and sucrose gradient purified P2 (P2) synaptosomes. Samples were separated by SDS-PAGE and proteins were identified by immunoblot. Note the enrichment of two presynaptic markers: CaV2.2 and Munc18. Approximately $15 \mathrm{mg}$ of protein was used for immunoblotting in A and 15 or $20 \mathrm{mg}$ in B. (B) Homogenates of whole rat brain (WB) lysates or synaptosomes (P2) were immunoblotted and assessed for the presence of various synaptic proteins as indicated. The proteins examined were: $\mathrm{CaV} 2.2$; the exocytosis/SNARE proteins syntaxin 1, NSF, and SNAP25; proteins of the cytomatrix at the active zone (CAZ) - RIM2, CAST, Munc13-1; the postsynaptic density and scaffolding protein PSD-95; and the clathrin adaptor protein AP180. $\beta$-actin was used both as a normalizing control as well as a marker for cytoskeletal matrix.

proteins syntaxin 1, NSF (n-ethylmaleimide sensitive fusion protein), and SNAP-25, as well as other presynaptic proteins including RIM (Rab3 interacting molecule), CAST (CAZassociated structural protein), and Munc13-1 were also enriched whereas the intensity of the bands for the endocytosis adaptor protein AP-180 and the ubiquitous matrix protein, actin, were similar in both lysates (Fig. 1). PSD-95 was also highly enriched in the synaptosomes, consistent with previous demonstrations that the postsynaptic density is

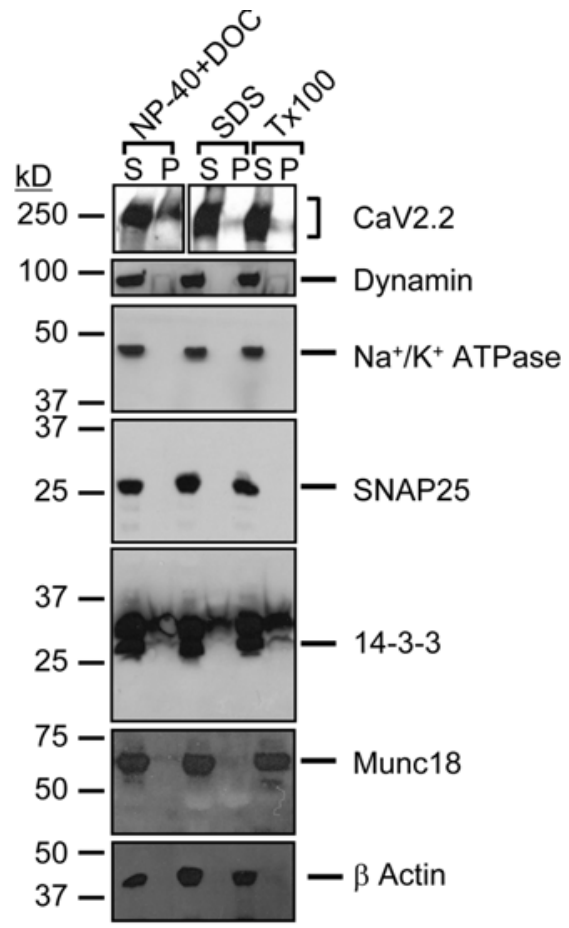

Fig. 2. Solubility of synaptic proteins in various detergents. Equal amounts $(\sim 30 \mathrm{mg})$ of proteins were extracted from the P2 synaptosome fraction with the indicated detergents and then separated into soluble (S) and pellet fractions (P). An aliquot of each fraction was analyzed by Western blotting using CaV2.2, dynamin, $\mathrm{Na}^{+} / \mathrm{K}^{+}$ATPase, SNAP25, 14-3-3, Munc18 and $\beta$-actin. The detergents and concentrations used were: $1 \% \mathrm{NP}-40+0.5 \%$ DOC, $2 \%$ SDS or $2 \%$ Tx- 100 .

routinely captured attached to the active zones of the presynaptic terminals (Fried and Blaustein, 1978).

Immunoprecipitation of CaV2.2 complexes from rat brain synaptosome lysate. We tested a range of detergent combinations to optimize conditions for solubilizing the synaptosomes while retaining protein complexes in the lysate. A combination of NP-40 and deoxycholate effectively solubilized synaptosome proteins, as indicated by a variety of presynaptic protein markers (Fig. 2).

We have previously reported that $\mathrm{CaV} 2.2$ can be immunoprecipitated with Ab571 bound to standard protein A coated agarose/sepharose beads, yielding a protein band on a Western blot that corresponds to the molecular weight of the channel $\alpha$-subunit (Li et al., 2004b) (Fig. 1, 2). We attempted to identify channel complex members by LC/MS/MS mass spectroscopy of denatured proteins from these beads but this failed as the samples were saturated with liberated rabbit antibody heavy chain. The problem was solved by covalent immobilization of the antibody on an amine-reactive gel matrix (Fig. 3). Paired controls were identical except for substitution with pre-immune rabbit IgG. Washing the control gels for 10 minutes reduced protein bands to below a visually 


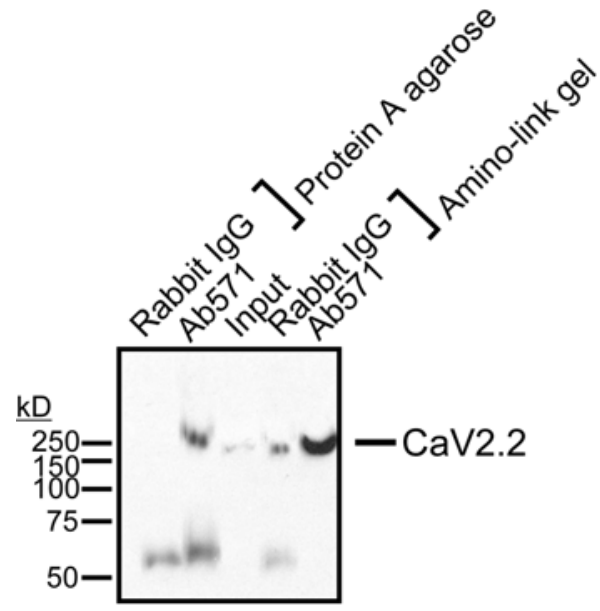

Fig. 3. Gel conjugated anti-CaV2.2 antibody captures the $\mathrm{Ca}^{2+}$ channel. Brain lysates ( $750 \mathrm{mg})$ were incubated with control rabbit IgG or Ab571 followed by recovery of immunoprecipitated proteins with Protein A agarose (left 2 lanes). Alternatively, the lysates were immunoprecipitated with antibodies (rabbit IgG or Ab571) conjugated to Aminolink gel matrix (rightmost 2 lanes; Pierce), and then washed and CaV2.2captured proteins were resolved on a 1D SDS-PAGE gel, transferred to PVDF membranes and immunoblotted with an anti-Cav2.2 (Ab571; $1: 500$ ). Approximately $2 \%$ of the starting material used for immunoprecipitation is loaded as a control (input lane). Molecular weight markers in kilodaltons $(\mathrm{kD})$ are indicated on the left.

detectable level, except for those corresponding to rabbit antibody (Fig. 4A, left lane). However, the Ab571 gel matrix exhibited many protein bands after 10 minutes washing (Fig. $4 \mathrm{~A}$, centre lane). The Ab571 gels used for proteomic analysis were washed for an additional 20 minutes to further ensure removal of non-specifically bound proteins (Fig. 4A, right lane). The experiment was carried out three separate times and the gel with the best defined protein bands (Fig. 4, right lane) was used for further analysis.

Identification of putative CaV2.2 binding partners. Further analysis was carried out on the Ab571 gel as, other than the IgG bands, the control gels were essentially devoid of staining and since our mass spectroscopy method fails to detect proteins below the sensitivity of Coomassie (R. Khanna, A. Zougman and E. F. Stanley, personal observations), they were not analyzed further. Protein bands on the Ab571 gel matrix blot ranged in molecular weight across the full extent of the blot ( $\sim 15$ to $600 \mathrm{kD})$. A semi-automatic gel cutter was used to recover 31 distinct bands from the gel lane in regions outside the IgG regions and each was analyzed separately. An example of an MS/MS spectrum of a band cut from the gel (Fig. 4A; asterisk) is shown (Fig. 4B).

Protein identification. Peptide sequences were searched against the NCBI database using online MASCOT software.
(A)

(B)
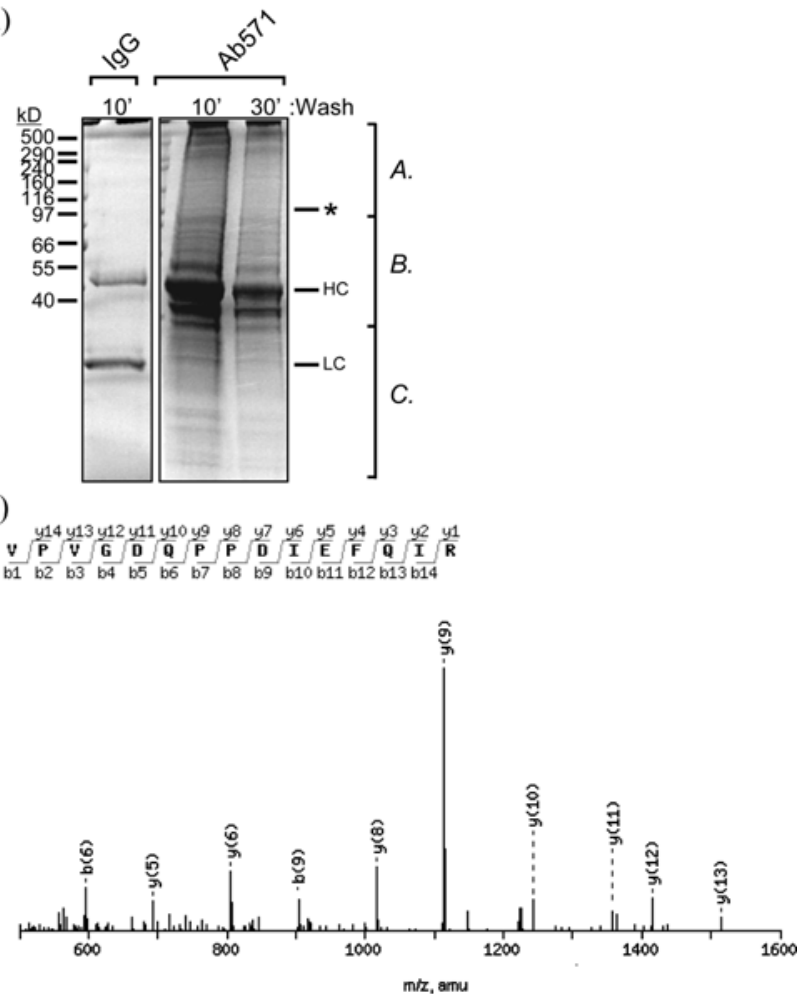

Fig. 4. Mass spectrometry analysis of CaV2.2-associated proteins. (A) Coomassie-stained gel showing immunoprecipitation (IP) from solubilized rat brain synaptosomes ( $2 \mathrm{mg}$ ) using rabbit IgG (left lane) or Ab571 conjugated to matrix (right two lanes). The samples were processed in an identical manner and were washed rigorously for the times indicated. Note the near absence of bands in the control except at molecular weights corresponding to antibody heavy and light chain (HC and LC, respectively). Individual bands were cut for further analysis from the three indicated regions (A-C; see Table 2), avoiding the IgG contaminated areas. All three lanes are from the same gel and are shown at the same exposure level. (B) An example of a MS/ MS spectrum of a peptide (of a trypsin digested product of $~ 95$ $110 \mathrm{kD}$ protein band indicated by the asterisk in A). A doubly charged ion at mass to charge ratio $(\mathrm{m} / \mathrm{z})$ of 855.91 , corresponding to a peptide of $1708.88 \mathrm{D}$, was selected for fragmentation by electrospray ionization induced dissociation. The fragment ions that originate either from the $\mathrm{N}$ terminus ( $b$ type ions) or the $\mathrm{C}$ terminus ( $y$ type ions) correspond to an amino acid sequence that was identified using the MASCOT database search program. In the example shown, the MS/MS spectrum matched the peptide sequence VPVGDQPPDIEFQIR from dynamin residues 143-157 (GenBank accession number: NP 542420.1). amu, atomic mass unit. $y$-axis, relative ion intensity in percentage.

The criteria for reliable protein identification were: the presence of a protein-specific, distinct and unique CID spectrum in our dataset combined with a MASCOT score greater than 50 . This yielded 589 peptide species corresponding to a total list of 104 unique proteins. The peptides ranged in length from 7 to 39 amino acid residues with the median length slightly over 
Table 2. Proteins co-precipitated from rat brain synaptosomes with the anti-CaV2.2 antibody Ab571

\begin{tabular}{|c|c|c|c|c|c|}
\hline Sample & Protein & $\begin{array}{l}\text { Size } \\
(\mathrm{kD})\end{array}$ & Group $^{\mathrm{b}}$ & Peptides $^{c}$ & $\begin{array}{l}\text { MASCOT } \\
\text { Score }^{\mathrm{d}}\end{array}$ \\
\hline $\mathrm{A} 01 *$ & Dynein, heavy chain & 534 & Cytoskeleton & $\begin{array}{l}\text { TTDLLTDWEK, VFEEDALSWEDKLNR, } \\
\text { FYFVGDEDLLEIIGNSK, } \\
\text { GIFEALRPLETLPVEGLIR, } \\
\text { TLHTTASNWLHLIPQTLSPLKR, } \\
\text { VTDFGDKVEDPTFLNQLQSGVNR }\end{array}$ & 130 \\
\hline A $05^{*}$ & $\beta$-Spectrin & 273 & Cytoskeleton & $\begin{array}{l}\text { HLLGVEDLLQK, SIITYVVTYYHYFSK, } \\
\text { SNAHYNLQNAFNLAEQHLGLTK }\end{array}$ & 155 \\
\hline A $05^{*}$ & $\alpha$-Spectrin & 273 & Cytoskeleton & $\begin{array}{l}\text { KVEDLFLFTAK, GVIDMGNSLIER + Oxidation (M), } \\
\text { LAALADQWQFLVQK, HQAFEAEVQANSGAIVK, } \\
\text { SADESGQALLAAGHYASDEVR, } \\
\text { NQALNTDNYGHDLASVQALQR }\end{array}$ & 320 \\
\hline A06* & $\begin{array}{l}\text { Microtubule associated } \\
\text { protein (MAP 1B) }\end{array}$ & 260 & $\begin{array}{l}\text { Growth cone/ } \\
\text { Adhesion }\end{array}$ & SVGNAIEPVILFQK & 65 \\
\hline A09* & Clathrin heavy chain & 193 & Endocytosis & $\begin{array}{l}\text { SVDPTLALSVYLR, ALEHFTDLYDIK, } \\
\text { VGYTPDWIFLLR, WLLLTGISAQQNR, } \\
\text { GQFSTDELVAEVEKR, LHIIEVGTPPTGNQPFPK, } \\
\text { AFMTASLPNELIELLEK, } \\
\text { LASTLVHLGEYQAAVDGAR, } \\
\text { KDPELWGSVLLESNPYR, } \\
\text { ISGETIFVTAPHEATAGIIGVNR, } \\
\text { LAELEEFINGPNNAHIQQVGDR, } \\
\text { ADDPSSYMEVVQAANTSGNWEELVK + Oxidation } \\
\text { (M) }\end{array}$ & 461 \\
\hline A $11 *$ & $\alpha$-catenin 2 & 105 & Cytoskeleton & GHTGIGELAAALNEFDNK & 51 \\
\hline $\mathrm{A} 11^{\#}$ & Adaptin $2 \alpha 2$ & 105 & Endocytosis & $\begin{array}{l}\text { FV FVNLFPEVK, THIETVINALK, } \\
\text { IAGDYVSEEVWYR, QLSNPQQEVQNIFK, } \\
\text { NAVLFEAISLIIHHDSEPNLLVR, } \\
\text { VVHLLNQDQHLGVVTAATSLITTLAQK, } \\
\text { IIGFGSALLEEVDPNPANFVGAGIIHTK }\end{array}$ & 232 \\
\hline A 11 & Adaptin $2 \beta 1$ & 106 & Endocytosis & LASQANIAQVLAELK, DIPNENELQFQIK & 130 \\
\hline A $12 *$ & Dynamin 1 & 98 & Endocytosis & VPVGDQPPDIEFQIR, ALLQMVQQFAVDFEK & 95 \\
\hline A 12 & $\begin{array}{l}\text { Neural cell adhesion } \\
\text { molecule (NCAM1) }\end{array}$ & 95 & $\begin{array}{l}\text { Growth cone/ } \\
\text { Adhesion }\end{array}$ & $\begin{array}{l}\text { GLGEISAATEFK, FFLCQVAGDAK, } \\
\text { FICVLSNNYLQIR, DIQVIVNVPPTVQAR, } \\
\text { CVVTAEDGTQSEATVNVNK, } \\
\text { VEPYSSTAQVQFDEPEATGGVPILK }\end{array}$ & 387 \\
\hline $\mathrm{B} 01^{*}$ & $\begin{array}{l}\text { Heat shock protein } \\
\text { (HSP90 } \alpha, \beta)\end{array}$ & 90 & Chaperone & $\begin{array}{l}\text { RAPFDLFENK, ADLINNLGTIAK, HFSVEGQLEFR, } \\
\text { TLTLVDTGIGMTK + Oxidation (M), } \\
\text { GVVDSEDLPLNISR, SLTNDWEDHLAVK, } \\
\text { HSXFIGYPITLYLEK,HNDDEQYAWESSAGGSFTVR }\end{array}$ & 397 \\
\hline B01 & $\begin{array}{l}\text { Heat shock protein } \\
\text { (HSP86) }\end{array}$ & 84 & Chaperone & $\begin{array}{l}\text { RAPFDLFENK, ADLINNLGTIAK, HFSVEGQLEFR, } \\
\text { TLTIVDTGIGMTK + Oxidation (M), } \\
\text { SXTNDWEEHLAVK, HNDDEQYAWESSAGGSFTVR, } \\
\text { QAQDQPMEEEEVETFAFQAEIAQLMSLIINTFYSNK }\end{array}$ & 291 \\
\hline B01 & $\begin{array}{l}\text { Double cortin } \mathrm{Ca} / \mathrm{CaM} \text { - } \\
\text { dependent protein kinase- } \\
\text { like } 1\end{array}$ & 84 & Cytoskeleton & $\begin{array}{l}\text { SFEALLADLTR, GGDLFDAITSTSK, } \\
\text { DASGMLYNLASAIK, TAHSFEQVLTDITDAIK, } \\
\text { FSAVQVLEHPWVNDDGLPENEHQLSVAGK }\end{array}$ & 136 \\
\hline $\mathrm{B} 02 *$ & $\begin{array}{l}\text { N-ethylmaleimide } \\
\text { sensitive fusion protein } \\
\text { (NSF) }\end{array}$ & 84 & Exocytosis-SNARE & $\begin{array}{l}\text { FSNLVLQALLVLLK, TPLVSVLLEGPPHSGK, } \\
\text { QKIEVGLVVGNSQVAFEK, } \\
\text { GSMAGSTGVHDTVVNQLLSK + Oxidation (M) }\end{array}$ & 141 \\
\hline B02 & Calnexin & 67 & $\begin{array}{l}\text { Endoplasmic } \\
\text { Reticulum }\end{array}$ & $\begin{array}{l}\text { GSLSGWILSK, VVDDWANDGWGLK, } \\
\text { APVPTGEVYFADSFDR, KIPNPDFFEDLEPFR }\end{array}$ & 230 \\
\hline
\end{tabular}


Table 2. Continued

\begin{tabular}{|c|c|c|c|c|c|}
\hline Sample & Protein & $\begin{array}{l}\text { Size } \\
(\mathrm{kD})\end{array}$ & Group $^{b}$ & Peptides $^{\mathrm{c}}$ & $\begin{array}{l}\text { MASCOT } \\
\text { Score }^{\mathrm{d}}\end{array}$ \\
\hline B03 & Drebrin-1 & 73 & Cytoskeleton & YVLINWVGEDVPDAR & 73 \\
\hline B04* & $\begin{array}{l}\text { Heat shock protein, } \\
\text { constitutive (HSC70) }\end{array}$ & 70 & Chaperone & $\begin{array}{l}\text { LLQDFFNGK, DAGTIAGLNVLR, FEELNADLFR, } \\
\text { NSLESYAFNMK + Oxidation (M), } \\
\text { SQIHDIVLVGGSTR, ARFEELNADLFR, } \\
\text { TTPSYVAFTDTER, SFYPEEVSSMVLTK + Oxidation } \\
\text { (M), IINEPTAAAIAYGLDK, STAGDTHLGGEDFDNR, } \\
\text { IINEPTAAAIAYGLDKK, } \\
\text { GPAVGIDLGTTYSCVGVFQHGK }\end{array}$ & 587 \\
\hline $\mathrm{B} 04^{\#}$ & Vacuolar $\mathrm{H}^{+}$ATPase & 70 & Exocytosis-SV & $\begin{array}{l}\text { DFPELTMEVDGK, ADYAQLLEDMQNAFR, } \\
\text { LEGDMATIQVYEETSGVSVGDPVLR }\end{array}$ & 79 \\
\hline B05* & $\begin{array}{l}\text { Protein phosphatase } 2 \mathrm{a} \\
(\mathrm{PP} 2 \mathrm{~A} \alpha, \beta)\end{array}$ & 66 & Signaling & SALASVIMGLSPILGK, DNTIEHLLPLFLAQLK & 65 \\
\hline B06 & $\begin{array}{l}\text { dihydropyriminidase } \\
\text { related protein (DRP1)/ } \\
\text { collapsin response } \\
\text { mediator protein } \\
\text { (CRMP1) }\end{array}$ & 62 & $\begin{array}{l}\text { Growth cone/ } \\
\text { Adhesion }\end{array}$ & $\begin{array}{l}\text { MDENQFVAVTSTNAAK, } \\
\text { IAVGSDADVVIWDPDKMK, } \\
\text { STVEYNIFEGMECHGSPLVVISQGK }\end{array}$ & 88 \\
\hline B06 & $\begin{array}{l}\text { Heat shock protein } \\
\text { (HSP60) }\end{array}$ & 61 & Chaperone & $\begin{array}{l}\text { TLNDELEIIEGMK, GVMLAVDAVIAELKK, } \\
\text { ISSVQSIVPALEIANAHR, IQEITEQLDITTSEYEKEK, } \\
\text { LVQDVANNTNEEAGDGTTTATVLAR, } \\
\text { TALLDAAGVASLLTTAEAVVTEIPKEEK }\end{array}$ & 314 \\
\hline $\mathrm{B} 07 *$ & $\beta$-actin & 42 & Cytoskeleton & $\begin{array}{l}\text { AVFPSIVGR, DLTDYLMK, DLTDYLMK, } \\
\text { GYSFTTTAER, EITALAPSTMK, IWHHTFYNELR, } \\
\text { QEYDESGPSIVHR, QEYDESGPSIVHR, } \\
\text { QEYDESGPSIVHR, SYELPDGQVITIGNER, } \\
\text { SYELPDGQVITIGNER, SYELPDGQVITIGNER, } \\
\text { SYELPDGQVITIGNER, VAPEEHPVLLTEAPLNPK, } \\
\text { VAPEEHPVLLTEAPLNPK, } \\
\text { LCYVALDFEQEMATAASSSSLEK, } \\
\text { YSVWIGGSILASLSTFQQMWISK, } \\
\text { TTGIVMDSGDGVTHTVPIYEGYALPHAILR, } \\
\text { YSVWIGGSILASLSTFQQMWISKQEYDESGPSIVHR }\end{array}$ & 450 \\
\hline B08 ${ }^{\#}$ & Gai & 41 & $\mathrm{G}$ protein & $\begin{array}{l}\text { TTGIVETHFTFK, WFTDTSIILFLNK, } \\
\text { IGAADYQPTEQDILR }\end{array}$ & 102 \\
\hline B08 ${ }^{\#}$ & Goo & 41 & $\mathrm{G}$ protein & $\begin{array}{l}\text { TTGIVETHFTFK, WFTDTSIILFLNK, } \\
\text { NVQFVFDAVTDVIIK }\end{array}$ & 109 \\
\hline B09 & Nogo-B/Reticulon 4 & 39 & $\begin{array}{l}\text { Growth cone/ } \\
\text { Adhesion }\end{array}$ & AYLESEVAISEELVQK & 57 \\
\hline $\mathrm{B} 10^{*}$ & $\alpha$-tubulin & 51 & Cytoskeleton & LIGQIVSSITASLR, IHFPLATYAPVISAEK & 136 \\
\hline $\mathrm{B} 10^{*}$ & syntaxin 1B & 33 & Exocytosis-SNARE & LAIFTDDIK, TTTNEELEDMLESGK & 115 \\
\hline B11 & $\mathrm{G} \beta$ & 31 & $\mathrm{G}$ protein & IIVDELKQEVISTSSK & 55 \\
\hline $\mathrm{B} 12^{*}$ & $\begin{array}{l}14-3-3 \\
(\zeta, \gamma)\end{array}$ & 26 & Signaling & $\begin{array}{l}\text { VAGMDVELTVEER, VAGMDVELTVEER + Oxidation } \\
\text { (M), AASDIAMTELPPTHPIR, } \\
\text { AASDIAMTELPPTHPIR + Oxidation (M) }\end{array}$ & 159 \\
\hline $\mathrm{C} 1^{*}$ & $\begin{array}{l}\text { Synaptobrevin/ } \\
\text { VAMP-A }\end{array}$ & 27 & Exocytosis-SNARE & $\begin{array}{l}\text { GLLSSLDHTSIR, } \\
\text { ALAEEVEVQDGPNEDGNMFMRPGK }\end{array}$ & 85 \\
\hline $\mathrm{C} 2$ & $\begin{array}{l}\text { 4-nitrophenylphosphatase } \\
\text { (NIP) domain and non- } \\
\text { neuronal SNAP25-like } \\
\text { protein (NIPSNAP) }\end{array}$ & 33 & Other & GWDENVYYTVPLVR, LKPGTMIEWGNNWAR & 81 \\
\hline
\end{tabular}


Table 2. Continued

\begin{tabular}{|c|c|c|c|c|c|}
\hline Sample $^{a}$ & Protein & $\begin{array}{l}\text { Size } \\
(\mathrm{kD})\end{array}$ & Group $^{\mathrm{b}}$ & Peptides $^{c}$ & $\begin{array}{l}\text { MASCOT } \\
\text { Score }^{\mathrm{d}}\end{array}$ \\
\hline $\mathrm{C} 4 *$ & RAB3a & 25 & Exocytosis- SV & TYSWDNAQVLLVGNK & 82 \\
\hline $\mathrm{C} 4$ & RALa & 24 & Signaling & VKEDENVPFLLVGNK & 192 \\
\hline $\mathrm{C} 5$ & $\begin{array}{l}\text { Tubulo-vesicle- } \\
\text { membrane-associated } \\
\text { GTP-binding protein }\end{array}$ & 23 & $\mathrm{G}$ protein & $\begin{array}{l}\text { QHSNSNMVIMLIGNK, DTFNHLTTWLEDAR, } \\
\text { IQEGVFDINNEANGIK, FQPVHDLTIGVEFGAR }\end{array}$ & 200 \\
\hline $\mathrm{C} 6^{*}$ & $\mathrm{Cdc} 42$ & 21 & Cytoskeleton & TPFLLVGTQIDLR & 52 \\
\hline $\mathrm{C} 7$ & Destrin & 19 & Cytoskeleton & YALYDASFETK, EILVGDVGVTITDPFK & 83 \\
\hline $\mathrm{C} 7 *$ & Stathmin & 17 & Cytoskeleton & $\begin{array}{l}\text { DLSLEEIQK, DLSLEEIQK, ASGQAFELILSPR, } \\
\text { SKESVPEFPLSPPK }\end{array}$ & 107 \\
\hline
\end{tabular}

*Proteins that could $(*)$, or could not $(*)$, be confirmed to co-immunoprecipitate with CaV2.2.

${ }^{a}$ Samples represent individual bands cut from a preparative 1D SDS-PAGE gel (see Fig. 4A) and digested with trypsin and processed for MS/MS analysis (Samples A01 (top of gel) to C7 (bottom of gel)).

${ }^{\mathrm{b}}$ The proteins were classified into functional groups.

${ }^{c}$ Tryptic peptides used for identification of each protein are listed. If peptides matched proteins from different species, the first match encountered in the rat data base is shown.

${ }^{\mathrm{d}}$ The MASCOT score $(\mathrm{S})$ is defined as $\mathrm{S}=-10 * \log (\mathrm{P})$, where $\mathrm{P}$ is the probability that the observed match is a random event. $\mathrm{S}$ scores greater than 50 were considered to be significant $(p<0.05$; Student's $t$-test $)$. Additional criteria for reliable protein identification included proteins with a protein-specific, distinct and unique CID spectrum in our dataset. See text for abbreviations.

16 amino acids, corresponding to about $13 \%$ sequence coverage observed per identified protein. The shortest peptide used to identify a protein based on a single peptide was 12 amino acid residues. Identified proteins ranged in size from 17 to $534 \mathrm{kD}$ and included a number of known presynaptic proteins (Table 2). Excluding proteins not meeting the above criteria, hypothetical or unknown proteins, mitochondrial proteins and metabolic enzymes or cofactors gave a finally tally of 40 selected synaptic proteins.

Classification of protein sets. The total list of 104 proteins was classified into specific functional groups (Fig. 5A). Cytoskeletal elements represented the largest category $(\mathrm{N}=19$ proteins) followed by signaling molecules (primarily small GTP-binding proteins; 14), mitochondrial proteins (13), metabolic enzymes (12), synaptic vesicle/fusion proteins (7), growth cone/adhesion (11), and chaperone proteins (7). Although synaptosome preparations generally include the postsynaptic apparatus attached to the presynaptic terminal (Phillips et al., 2001) (Fig. 1), no postsynaptic density (PSD) marker proteins were recovered with the $\mathrm{Ca}^{2+}$ channel. We also generated a 'synapse related' subset of 40 proteins that were classified into the same functional categories (Fig. 5B).

Screen for CAZ complex proteins. Previous studies have reported the presence of a multi-molecular complex associated with neurosecretory structures termed the CAZ that includes bassoon, piccolo, together with Munc13, CAST and RIM and that has been hypothesized to play a major role in synaptic organization (Dresbach, Qualmann, Kessels, Garner and
Gundelfinger, 2001; Ziv and Garner, 2004). However, no member of this complex was detected in our CaV2.2-associated proteome. One possible explanation for this omission was that our lysis buffer failed to solubilize these proteins, some of which are exceptionally large. We tested this possibility by spinning down insoluble particulate matter and comparing the supernatant and pellet fractions for protein composition by Western blot. All the CAZ proteins were retrieved primarily in the soluble fraction, demonstrating that they were solubilized in the NP-40/deoxycholate-containing RIPA buffer (Fig. 6). Thus, the primary CAZ complex members were present in the soluble fraction of our synaptosome lysate.

\section{Discussion}

We have carried out the first open screen for putative CaV2.2 binding partners in presynaptic nerve terminals. We demonstrate that channel-associated proteins can be captured by immunoprecipitation and identified by LC/MS/MS analysis. Many known CaV2.2 channel interacting proteins were identified together with a number of novel partners, providing a protein partner list of value for the understanding of presynaptic CaV2.2 biology.

Several previous studies have used mass spectroscopy analysis to identify the spectrum of proteins present at synapses. Our objective was to isolate and characterize the sub-set of these proteins that are associated with the $\mathrm{N}$ type $\mathrm{Ca}^{2+}$ channel. Proteomic analysis is, however, subject to methodological variables that can have a marked impact on 


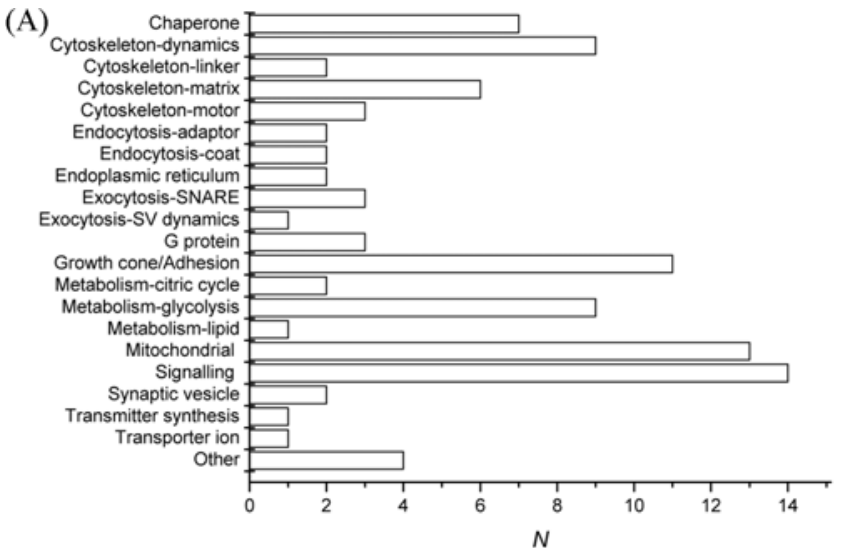

(B)

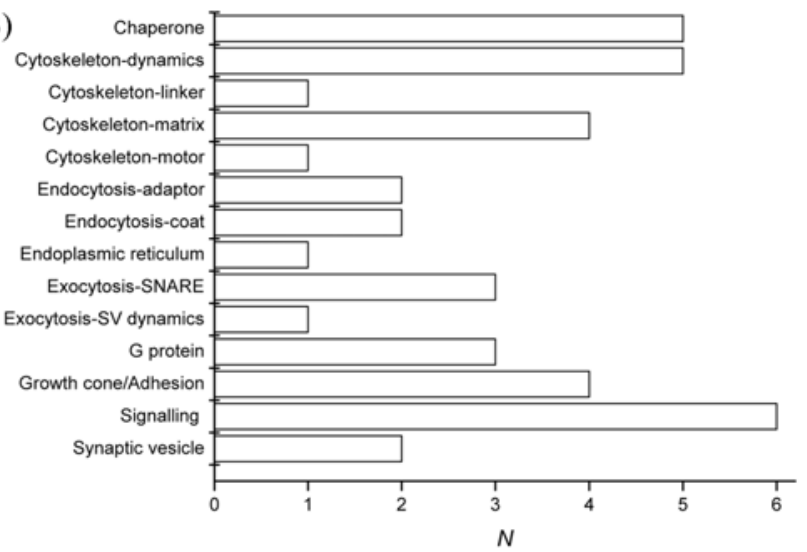

Fig. 5. Classification of CaV2.2 complex proteins. (A) The 104 unique proteins identified in the CaV2.2 immunoprecipitation from synaptosomes were classified into 21 functional groups. (B) The subset of 40 high-confidence, synapse-associated proteins were classified into 14 functional groups. $N$, number of proteins in each category.

the resulting identified protein set. In addition to the quality, quantity and complexity of the starting materials these variables include: the lysis buffer composition, in particular the detergent type and concentration; the mass spectroscopy method and the protein identification stringency. The use of immunoprecipitation to isolate the protein subset in this study adds three other key factors to this list: the tissue lysis and IP buffer, the selectivity and affinity of the antibody, and the wash stringency after immunoaffinity enrichment.

The choice and concentration of lysis buffer detergent inevitably involves a compromise between protein solubilization, on the one hand, and maintenance of protein complex integrity, on the other. We used a combination of the non-ionic detergent NP-40 (1\%) together with the anionic detergent deoxycholate $(0.5 \%)$. A similar combination has been used previously to retain protein complexes (e.g. Husi, Ward, Choudhary, Blackstock and Grant, 2000; Phillips et al., 2001) and also for the solubilization of detergent-resistant proteins, such as Piccolo and Bassoon (Takao-Rikitsu et al., 2004; Dieck et al., 2005).

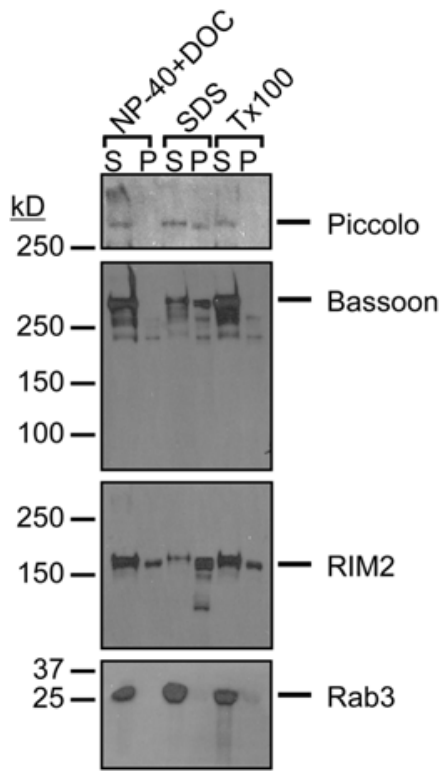

Fig. 6. CAZ complex proteins are solubilized in the modified RIPA buffer. The solubility of proteins ( $\sim 25 \mathrm{mg}$ per lane) of the CAZ family was examined as described (see Fig. 2).

CaV2.2 binding proteins. In this study we searched for proteins that co-precipitate with immobilized CaV2.2. This resulted in the identification of 104 putative CaV2.2 binding partners. However, it was also interesting to note which proteins, or protein classes were not captured in the screen. Possible reasons for omission include a concentration below detection threshold, post-translational modifications obscuring the peptide signature, or specific methodological factors. In addition, some classes of proteins such as integral membrane proteins are generally difficult to detect. Curiously, CaV2.2 itself was not identified in the mass spectroscopy analysis of our gel proteins. This is, however, consistent with previous studies using similar analysis methods, none of which have detected CaV2.2 by mass spectroscopy (Peng et al., 2004; Schrimpf et al., 2005; Witzmann et al., 2005). Indeed, the only CaV2.x channel alpha subunit detected to date was CaV2.3 and the confidence in this 'hit' was low $(<10 \%)$ with a Mascot score of 11 ( $\mathrm{Li}$ et al., 2004a). Enrichment of glycosylated proteins also identified a $\mathrm{T}$ type $\mathrm{Ca}^{2+}$ channel family member (Witzmann et al., 2005) while an L type channel was detected in a screen of PSD proteins (Peng et al., 2004). Even though we did not detect the channel itself, the direct demonstration of CaV2.2 capture on the matrix by Western blot analysis and the selective capture of known CaV2.2 binding partners ensure that the channel is indeed present. The absence of the channel could be simply due to the fact that certain proteins are more or less likely to surface in the screen and transmembrane proteins in particular may be hard to detect. An alternative explanation is that since many of the associated proteins can be assumed to be bound indirectly to the channel, their effective concentration in the complex is 
far higher. However, it should be noted that the absence of the channel increases the likelihood that other, in particular intrinsic membrane proteins, were likely missed in the screen.

Mass spectroscopy of CaV2.2 complex partners identified a broad range of proteins that fell into a number of categories and sub-categories. In order to test if this protein list reflected a distinct CaV2.2 complex-enriched population we compared the classes and specific protein types to a pooled list of proteins detected by Schrimpf et al. and Witzmann et al., herein termed the 'synaptosome proteome'. This synaptosome proteome was generated by identifying the unique members from the shotgun (analysis of the whole solubilized synaptosome) and 2D gel lists reported by Schrimpf et al. and Witzmann et al. However, it should be noted that the list from Schrimpf et al. is described as 'selected' and hence, does not include the entire list of proteins detected in the synaptosome isolate. Further, our study used rat neonates whereas the Schrimpf report used 'mouse brains' (of an unspecified age) and the Witzmann study adult rat brains. The neonates were favored here to maximize CaV2.2 recovery (Jones et al., 1997). The synaptosome proteome was catalogued into 21 broad functional groups (Fig. 7A). These were then compared to a similar catalogue of our CaV2.2 binding partner list (Supplementary Table 1). Due to the identification of subunits and slight differences in terminology this comparison required a few simplifications and assumptions but these should not materially affect the overall conclusions.

A key indication that our CaV2.2 set reflected a distinct subgroup of proteins was that we did not detect any nonneuronal proteins whereas $2.5 \%$ (7) of the synaptosome proteome list were obviously from cells that contaminated the sample. Indeed, this may be an underestimate since all of the non-neuronal proteins were derived from the Witzmann study and, hence, we do not know if additional non-neuronal proteins were prefiltered from the Schrimpf list. Some synaptosome proteome and CaV2.2 categories exhibited similar percentages, including endocytosis, SNARE-exocytosis, and cytoplasmic signaling proteins. There were also, however, a number of significant differences: our study identified relatively more chaperone, catabolic and cytoskeletal and small signaling proteins whereas it exhibited less metabolic, PSD, scaffold, and transmitter transporter proteins. The absence of PSD proteins is of particular significance with respect to the argument for a selected protein set. As mentioned above, the PSD typically remains attached to the presynaptic terminal in the purified synaptosome (Fried et al., 1978; Phillips et al., 2001; Witzmann et al., 2005) (see also Fig. 1). The absence of PSD proteins in our MS analysis is compelling evidence for a distinct and selected CaV2.2 protein set. An analysis of individual proteins (Fig. 7B) provided further evidence for a CaV2.2-associated subset. Although there were a large number of small $\mathrm{G}$ proteins $(\sim 7 \%$ synaptosome, $N=11$; $\sim 11.5 \% \mathrm{CaV} 2.2, N=19$ ), only Rab3a (classified generally as a secretory vesicle-associated proteins) was in common. Overall, the proteins associated with $\mathrm{CaV} 2.2$ represent a distinct
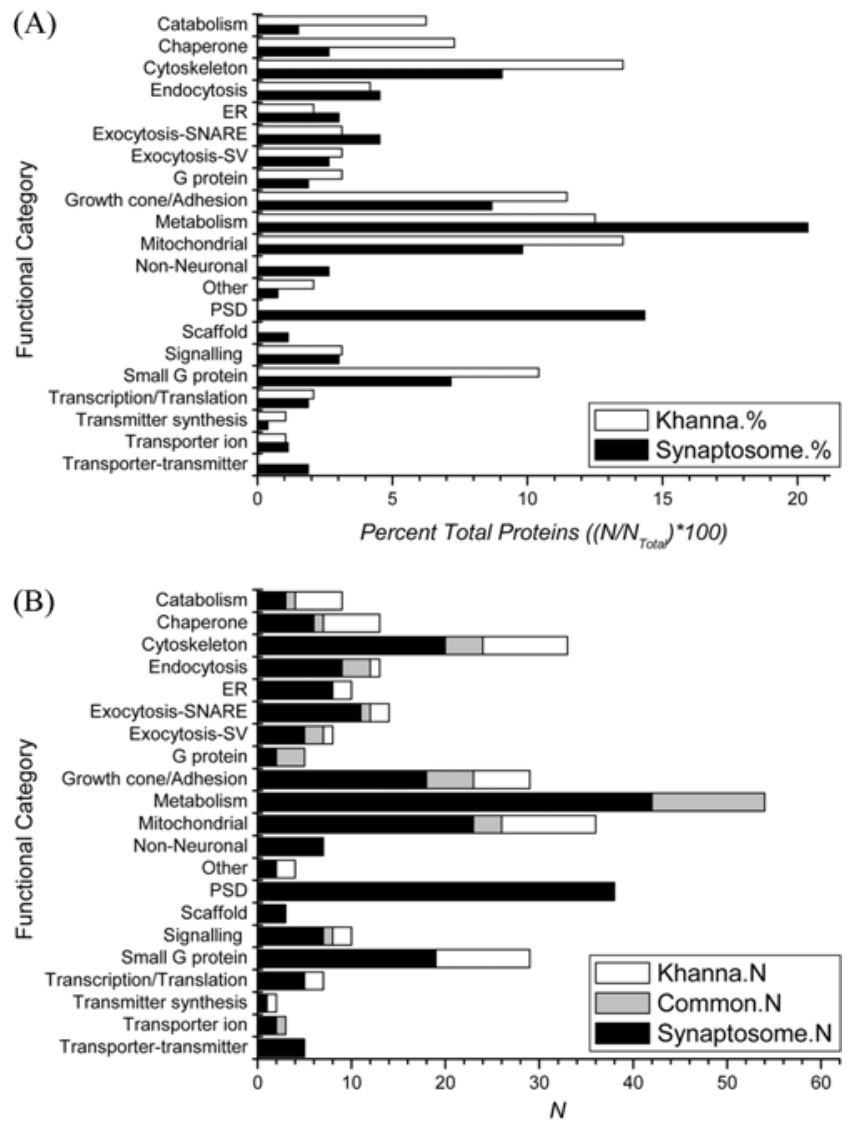

Fig. 7. Comparison of the CaV2.2 proteins to the synaptosome proteome. The protein list from this study was compared to a pooled synaptosome proteome (see text). (A) Relative distribution of protein numbers classified into functional classes. (B) Degree of protein species overlap. Each functional group shows the number of proteins identified only in synaptosome proteome (black bar), the number of proteins identified associated with the CaV2.2 channel (white bar) and the number identified in both protein sets (grey bar). $\mathrm{N}=$ number of proteins.

set comprising both elements of the Schrimpf synaptosome proteome together with unique additional CaV2.2-associated protein elements.

\section{Identified proteins}

Exocytosis and secretory vesicle proteins. A number of proteins known to be associated with secretory vesicle dynamics and exocytosis were isolated together with CaV2.2. These include syntaxin 1, VAMP, spectrin and NSF. Syntaxin 1 was the first CaV2.2 binding partner (Saisu, Ibaraki, Yamaguchi, Sekine and Abe, 1991; Bennett, Calakos and Scheller, 1992) and VAMP has also been reported as a CaV2.2 binding partner (El Far et al., 1995). A recent report indicates that presynaptic $\mathrm{Ca}^{2+}$ channels are linked to nonerythroid spectrin (Sunderland et al., 2000). However, NSF and Rab3a are new putative CaV2.2 complex partners. Rab3a 
is of considerable interest since this small $G$ protein is a secretory vesicle-associated protein known to be involved in vesicle transport signaling. In addition, it also binds to RIM, (Rab3a Interacting Molecule), a key release site protein involved in synaptic vesicle docking/priming (Geppert, Goda, Stevens and Südhof, 1997; Calakos, Schoch, Sudhof and Malenka, 2004). However, RIM itself does not co-precipitate with the channel (Khanna et al., 2006). Thus, our study identifies Rab3a as a potential RIM-CaV2.2 signaling protein. Other proteins associated with the SV itself or its docking/ fusion identified in the synaptosome proteome.

Postsynaptic density proteins. As mentioned above, the synaptosome proteome typically includes a number of proteins associated with the postsynaptic density. This structure is captured together with the presynaptic terminals due to strong trans-synaptic linkages via neurexins, cadherins amongst other synapse-spanning protein bridges (Phillips et al., 2001). The PSD is solubilized in our detergent conditions and, hence, was available for co-precipitation. Hence, the stark absence of any PSD proteins in our screen argues against the idea that the $\mathrm{Ca}^{2+}$ channel itself is a part of a trans-synaptic bridge that anchors the relase site and is consistent with our recent findings (Sun et al., 2006).

Scaffold proteins. The pooled synaptosome proteome includes a number of proteins that have been suggested to play a key role in synaptic organization including the massive proteins Bassoon and Piccolo and the modular adaptor CASK. None of these were detected with CaV2.2.

Growth cone/Adhesion proteins. CaV2.2 has been reported to be present in axonal growth cones (Vigers and Pfenninger, 1991) although its role in the function of this structure is not known. Its association here with nogo and neurochondrin and also the extracellular adhesion protein NCAM-1 suggests that a role in growth cone biology warrants further examination.

$\mathrm{Ca}^{2+}$ channel modulating proteins. It is well established that presynaptic CaV2.2 channels are modulated via a distinct set of presynaptic metabotropic receptors (Qian et al., 1997; Mirotznik et al., 2000) and their associated trimeric $(\alpha \beta \gamma) \mathrm{G}$ proteins. The capture of $\mathrm{G}_{\mathrm{O} \alpha} / \mathrm{G}_{\mathrm{I} \alpha}$ and $\mathrm{G}_{\beta}$ is consistent with a CaV2.2/syntaxin $1 / \mathrm{G}_{\mathrm{O} \alpha}$ complex (Li et al., 2004b) while the co-precipitation of $\mathrm{PP} 2 \mathrm{~A}$ provides support for an interaction of this protein with $\mathrm{N}$ type $\mathrm{Ca}^{2+}$ channels (Li et al., 2005).

Cytoskeleton. CaV2.2 was associated with a range of cytoskeletal elements including actin and spectrin, two matrix components, together with a number of cytoskeletal cross linkers, dynamic regulators and motors (dynein and myosin). While some of these may reflect transport of the channel to or from the transmitter release face, previous studies have suggested that such cytoskeletal linkages play a role in channel clustering or localization at the transmitter release site. Thus, actin, spectrin, $\alpha$-catenin, and dynein are all components of the particle web presynaptic complex (Phillips et al., 2001) while spectrin has been suggested to link the $\mathrm{Ca}^{2+}$ channel to the secretory vesicles (Sunderland et al., 2000) (see below).

Metabolism. A number of enzymes associated with the citric acid cycle and glycolysis were recovered with $\mathrm{CaV} 2.2$. These are prominent components of the synaptosome proteome (Schrimpf et al., 2005; Witzmann et al., 2005) reflecting their importance in neural metabolism.

Endocytosis. Clathrin heavy chain, a key endocytosis coat protein, and dynamin the pinocytosis scission protein were both detected in the CaV2.2 screen. Recent studies have suggested that the active zone may be linked directly to an endocytotic region (Marie et al., 2004; Koh et al., 2004).

CaV2.2 at the presynaptic nerve terminal. The spectrum of CaV2.2-associated proteins implicate the $\mathrm{Ca}^{2+}$ channel in a number of aspects of nerve terminal biology, including the growth cone and, as might be expected, in protein transport pathways. Perhaps the most interesting aspect of this study is its implications for the organization of the transmitter release site. Three main cytoplasmic complexes have been suggested to play a key role in the organization of the transmitter release site: a complex of modular adaptor proteins CASK, MINT and Veli which has been suggested to be attached directly to the channel and to the neurexin and neuroligin transsynaptic bridge (Maximov and Bezprozvanny, 2002); the CAZ that includes the scaffold proteins Bassoon and Piccolo (Dresbach et al., 2001); and the particle web, composed of a number of scaffold, endocytosis and cytoplasmic matrix components (Phillips et al., 2001).

The failure to detect any of the modular adaptor proteins or components of the trans-synaptic bridge in this screen strengthens the argument against a major channel scaffolding role for this complex (Khanna et al., 2006).

A number of studies have characterized a multi-molecular presynaptic structure termed the CAZ complex with cardinal components composed of the two high molecular weight proteins bassoon and piccolo together with RIM, Munc13 and CAST that has been suggested to play a key role in the organization of the active zone. However, all of these proteins were absent in our screen. One possibility was that these were missing because of incomplete solubilization. However, we found that all the major components of CAZ were present in the soluble fraction with our NP-40/deoxycholate detergent combination (Fig. 6). In addition, the CAZ complex appeared to be relatively intact under these conditions since we were able to co-precipitate its key components, including bassoon, RIM, CAST and Munc-13 with an anti-piccolo antibody (data not shown). Thus, our results do not support the idea that the $\mathrm{CaV} 2.2$ channel is tethered to the release site by the CAZ complex. Our results suggest, therefore, hat the synaptosome 
CaV2.2 is not anchored to the $C A Z$.

In contrast to the $C A Z$ complex we identified a number of proteins that have been associated with the presynaptic particle web complex (Phillips et al., 2001; Phillips et al., 2005). These include NSF, syntaxin 1, HSP70, tubulin, $\alpha$ - and $\beta$-spectrin, clathrin, v-ATPase and dynamin and supports the hypothesis that a particle web-like complex is involved in the anchoring of $\mathrm{Ca}^{2+}$ channels at the presynaptic terminal. Although the list of presynaptic CaV2.2 protein complex partners presented here is clearly not comprehensive, it yet serves as a starting point for further studies on the release face $\mathrm{Ca}^{2+}$ channel complex molecular composition and also for possible roles for this channel in other nerve terminal biological mechanisms.

Acknowledgments We are grateful to Qi Li, Allen Chan, Fiona Wong, Drs. Paul Taylor (Protana Inc.) and Steven Owens for discussions; Dr. Gerold Schmitt-Ulms (CRND, University of Toronto) for critical discussions about mass spectrometry; Dr. L.C. Schlichter for animal material and Lin Guo and Chris Smith (Protana Inc.) for technical assistance. This study was supported by CIHR awards MOP67153 and 57716, and a Canada Research Chair (EFS). This work has been presented in abstract form: R. Khanna, Q. Li, A. Zougman, E.F. Stanley. Program No. 963.3. 2005 Abstract Viewer/Itinerary Planner. Washington, DC: Society for Neuroscience, 2005. Online; Khanna, R., Li, Q., Sun, L., Zougman, A., and Stanley, E.F. (2006) Biophys. J. 90, 257a; E.F. Stanley, R. Khanna, Q. Li, L. Sun, A. Zougman, T.J. Collins, Federation of European Neurosciences 2006).

\section{References}

Atlas, D. (2001) Functional and physical coupling of voltagesensitive calcium channels with exocytotic proteins: ramifications for the secretion mechanism. J. Neurochem. 77, 972-985.

Bennett, M. K., Calakos, N. and Scheller, R. H. (1992) Syntaxin: A synaptic protein implicated in docking of synaptic vesicles at presynaptic active zones. Sci. 257, 255-259.

Blackstone, C. D., Moss, S. J., Martin, L. J., Levey, A. I., Price, D. L. and Huganir, R. L. (1992) Biochemical characterization and localization of a non-N-methyl-D-aspartate glutamate receptor in rat brain. $J$. Neurochem. 58, 1118-1126.

Calakos, N., Schoch, S., Sudhof, T. C. and Malenka, R. C. (2004) Multiple roles for the active zone protein RIM1alpha in late stages of neurotransmitter release. Neuron 42, 889-896.

Dieck T. S., Altrock, W. D., Kessels, M. M., Qualmann, B., Regus, H., Brauner, D., Fejtova, A., Bracko, O., Gundelfinger, E. D. and Brandstatter, J. H. (2005) Molecular dissection of the photoreceptor ribbon synapse: physical interaction of Bassoon and RIBEYE is essential for the assembly of the ribbon complex. J. Cell Biol. 168, 825-836.

Dresbach, T., Qualmann, B., Kessels, M. M., Garner, C. C. and Gundelfinger, E. D. (2001) The presynaptic cytomatrix of brain synapses. Cell Mol. Life Sci. 58, 94-116.

El Far, O., Charvin, N., Leveque, C., Martin-Moutot, N.,
Takahashi, M. and Seagar, M. J. (1995) Interaction of a synaptobrevin (VAMP)-syntaxin complex with presynaptic calcium channels. FEBS Letters, 361, 101-105.

Fried, R. C. and Blaustein, M. P. (1978) Retrieval and recycling of synaptic vesicle membrane in pinched-off nerve terminals (synaptosomes). J. Cell Biol. 78, 685-700.

Geppert, M., Goda, Y., Stevens, C. F. and Südhof, T. C. (1997) The small GTP-binding protein Rab3A regulates a late step in synaptic vesicle fusion. Nature (Lond.) 387, 810-814.

Husi, H., Ward, M. A., Choudhary, J. S., Blackstock, W. P. and Grant, S. G. (2000) Proteomic analysis of NMDA receptoradhesion protein signaling complexes. Nat. Neurosci. 3, 661669.

Ishikawa, H., Shimada, O., Murakami, T., Saisu, H. and Abe, T. (1993) Immunohistochemical localization of the proteins associated with brain N-type calcium channels. Ann. N.Y. Acad. Sci. 707, 376-378.

Jones, O. T., Bernstein, G. M., Jones, E. J., Jugloff, D. G., Law, M., Wong, W. and Mills, L. R. (1997) N-Type calcium channels in the developing rat hippocampus: subunit, complex, and regional expression. J. Neurosci. 17, 6152-6164.

Khanna, R., Li, Q., Sun, L., Collins, T. J. and Stanley, E. F. (2006) $\mathrm{N}$ type $\mathrm{Ca}(2+)$ channels and RIM scaffold protein covary at the presynaptic transmitter release face but are components of independent protein complexes. Neurosci. 140, 1201-1208

Khanna, R., Sun, L., Li, Q., Guo, L. and Stanley, E. F. (2006) Long splice variant $\mathrm{N}$ type calcium channels are clustered at presynaptic transmitter release sites without modular adaptor proteins. Neurosci. 138, 1115-1125.

Koh, T. W., Verstreken, P. and Bellen, H. J. (2004) Dap160/ intersectin acts as a stabilizing scaffold required for synaptic development and vesicle endocytosis. Neuron 43, 193-205.

Lau, L. F., Mammen, A., Ehlers, M. D., Kindler, S., Chung, W. J., Garner, C. C. and Huganir, R. L. (1996) Interaction of the Nmethyl-D-aspartate receptor complex with a novel synapseassociated protein, SAP102. J. Biol. Chem. 271, 21622-21628.

Li, D., Wang, F., Lai, M., Chen, Y. and Zhang, J. F. (2005) A protein phosphatase 2calpha-Ca2+ channel complex for dephosphorylation of neuronal $\mathrm{Ca} 2+$ channels phosphorylated by protein kinase C. J .Neurosci. 25, 1914-1923.

Li, K. W., Hornshaw, M. P., Van der Schors, R. C., Watson, R., Tate, S., Casetta, B., Jimenez, C. R., Gouwenberg, Y., Gundelfinger, E. D., Smalla, K. and Smit, A. B. (2004a) Proteomics analysis of rat brain postsynaptic density. Implications of the diverse protein functional groups for the integration of synaptic physiology. J. Biol. Chem. 279, 9871002.

Li, Q., Lau, A., Morris, T. J., Guo, L., Fordyce, C. B. and Stanley, E. F. (2004b) A syntaxin 1, Galpha(o), and N-type calcium channel complex at a presynaptic nerve terminal: analysis by quantitative immunocolocalization. J. Neurosci. 24, 4070-4081.

Marie, B., Sweeney, S. T., Poskanzer, K. E., Roos, J., Kelly, R. B. and Davis, G. W. (2004) Dap160/intersectin scaffolds the periactive zone to achieve high-fidelity endocytosis and normal synaptic growth. Neuron 43, 207-219.

Maximov, A. and Bezprozvanny, I. (2002) Synaptic targeting of N-type calcium channels in hippocampal neurons. J. Neurosci. 22, 6939-6952.

Maximov, A., Sudhof, T. C. and Bezprozvanny, I. (1999) 
Association of neuronal calcium channels with modular adaptor proteins. J. Biol. Chem. 274, 24453-24456.

Mirotznik, R. R., Zheng, X. and Stanley, E. F. (2000) G-Protein types involved in calcium channel inhibition at a presynaptic nerve terminal. $J$. Neurosci. 20, 7614-7621.

Peng, J., Kim, M. J., Cheng, D., Duong, D. M., Gygi, S. P. and Sheng, M. (2004) Semiquantitative proteomic analysis of rat forebrain postsynaptic density fractions by mass spectrometry. J. Biol. Chem. 279, 21003-21011.

Perkins, D. N., Pappin, D. J., Creasy, D. M. and Cottrell, J. S. (1999) Probability-based protein identification by searching sequence databases using mass spectrometry data. Electrophoresis 20, 3551-3567.

Phillips, G. R., Florens, L., Tanaka, H., Khaing, Z. Z., Fidler, L., Yates, J. R., III and Colman, D. R. (2005) Proteomic comparison of two fractions derived from the transsynaptic scaffold. J. Neurosci. Res. 81, 762-775

Phillips, G. R., Huang, J. K., Wang, Y., Tanaka, H., Shapiro, L., Zhang, W. et al. (2001) The presynaptic particle web: ultrastructure, composition, dissolution, and reconstitution. Neuron 32, 63-77.

Qian, J., Colmers, W. F. and Saggau, P. (1997) Inhibition of synaptic transmission by neuropeptide $\mathrm{Y}$ in rat hippocampal area CA1: Modulation of presynaptic $\mathrm{Ca}^{2+}$ entry. J. Neurosci. 17, 8169-8177.

Saisu, H., Ibaraki, K., Yamaguchi, T., Sekine, Y. and Abe, T. (1991) Monoclonal antibodies immunoprecipitating omegaconotoxin- sensitive calcium channel molecules recognize two novel proteins localized in the nervous system. Biochem. Biophys. Res. Commun. 181, 59-66.

Schmitt-Ulms, G., Hansen, K., Liu, J., Cowdrey, C., Yang, J., DeArmond, S. J., Cohen, F. E., Prusiner, S. B. and Baldwin, M. A. (2004) Time-controlled transcardiac perfusion crosslinking for the study of protein interactions in complex tissues. Nat. Biotechnol. 22, 724-731.

Schrimpf, S. P., Meskenaite, V., Brunner, E., Rutishauser, D., Walther, P., Eng, J., Aebersold, R. and Sonderegger, P. (2005) Proteomic analysis of synaptosomes using isotope-coded affinity tags and mass spectrometry. Proteomics 5, 2531-2541.

Sheng, Z. H., Westenbroek, R. E. and Catterall, W. A. (1998)
Physical link and functional coupling of presynaptic calcium channels and the synaptic vesicle docking/fusion machinery. $J$. Bioenerg. Biomembr. 30, 335-345.

Shevchenko, A., Wilm, M., Vorm, O. and Mann, M. (1996) Mass spectrometric sequencing of proteins silver-stained polyacrylamide gels. Anal.Chem. 68, 850-858.

Spafford, J. D., Munno, D. W., Van Nierop, P., Feng, Z. P., Jarvis, S. E., Gallin, W. J., Smit, A. B., Zamponi, G. W. and Syed, N. I. (2003) Calcium channel structural determinants of synaptic transmission between identified invertebrate neurons. J. Biol. Chem. 278, 4258-4267

Stanley, E. F. (1997) The calcium channel and the organization of the presynaptic transmitter release face. Trends Neurosci. 20, 404-409.

Sun, L., Li, Q., Khanna, R., Chan, A. W., Wong, F. and Stanley, E. F. (2006) Transmitter release face Ca channel clusters persist at isolated presynaptic terminals. Eur. J. Neurosci. 23, 13911396.

Sunderland, W. J., Son, Y. J., Miner, J. H., Sanes, J. R. and Carlson, S. S. (2000) The presynaptic calcium channel is part of a transmembrane complex linking a synaptic laminin (alpha4beta2gamma1) with non-erythroid spectrin. J. Neurosci. 20, 1009-1019.

Takao-Rikitsu, E., Mochida, S., Inoue, E., guchi-Tawarada, M., Inoue, M., Ohtsuka, T. and Takai, Y. (2004) Physical and functional interaction of the active zone proteins, CAST, RIM1, and Bassoon, in neurotransmitter release. J. Cell Biol. 164, 301-311.

Vigers, A. J. and Pfenninger, K. H. (1991) N-type and L-type calcium channels are present in nerve growth cones. Numbers increase on synaptogenesis. Brain Res. Dev. Brain Res. 60, 197-203.

Witzmann, F. A., Arnold, R. J., Bai, F., Hrncirova, P., Kimpel, M. W., Mechref, Y. S., McBride, W. J., Novotny, M. V., Pedrick, N. M., Ringham, H. N. and Simon, J. R. (2005) A proteomic survey of rat cerebral cortical synaptosomes. Proteomics 5, 2177-2201.

Ziv, N. E. and Garner, C. C. (2004) Cellular and molecular mechanisms of presynaptic assembly. Nat. Rev. Neurosci. 5, 385-399. 